\title{
nature
}

1 January 2004 Volume 427 Issue no 6969

\section{Complacency about misconduct}

Plagiarism is a serious sin, but universities and journals do not always respond appropriately. A case reported this week suggests that some in the physical sciences have yet to appreciate the threat to confidence in science.

$\mathrm{R}$ esearchers who choose to deceive their colleagues can adopt a variety of strategies. Details of a physicist who employed a low-risk, low-reward approach — the plagiarizing of papers from foreign-language journals — came to light this week. And although the fraud produced papers that have amassed few citations, the response of the researcher's peers is cause for concern.

Yung Park was certainly no Jan Hendrik Schön. The latter was a high-profile young physicist at the prestigious Bell Laboratories in Murray Hill, New Jersey. When suspicions about Schön surfaced in May 2002, his employers went public, launched an inquiry, and helped to ensure that journals were alerted promptly so that their readers were soon aware of the problem. Schön was found to have fabricated and falsified data in 25 papers - and physicists agreed that they needed to take a hard look at how they handled cases of misconduct.

Responses to Park's misconduct have been less commendable. Between 1995 and 2002, while at the Korea Advanced Institute of Science and Technology (KAIST) in Daejeon, and then as a visiting scientist at the University of Cambridge, UK, Park published about 80 papers in materials science. At least eight of these are plagiarisms, most of them almost identical copies of papers originally published in Russian. When confronted by the evidence in April 2002, Park left Cambridge and his whereabouts are now unknown (see page 3 ).

Unfortunately for researchers who work in Park's field the study of electronic properties of materials - Park's former colleagues at Cambridge failed to notify journal editors of some of the plagiarisms that they uncovered. Some editors who were informed by KAIST took no action. As a result, at least four known plagiarisms remain available in journals.

Four papers, all of low impact, may not seem much cause for concern. This indeed seems to have been the attitude of many of those involved. But although journal editors and researchers contacted by Nature insist on the need to combat plagiarism, their lack of action indicates that parts of the physics community feel that it is not their responsibility to deal with misconduct.

This is odd, as simple steps can help put right plagiarism of the type practised by Park. The journal Solid State Communications published a paper by Park that is now known to have been plagiarized. The editors have attached a note to the online version of the paper, marking it as a plagiarism and directing readers to the original work. The journal has also published a note in print. Together, these measures should minimize any loss of citations that the author of the original paper might suffer, and make it clear that Park is guilty of misconduct.

Research institutions have responsibilities too. As a visiting scientist, Park was not paid by Cambridge. But he worked in the university's labs and published under its affiliation. The university therefore has a duty to investigate all of the 40 or so papers published by Park while he was there, and to make the results of that assessment available to journal editors and the research community.

The effect of not taking such steps is clear. Authors of the original papers lose out on citations, and the chance that Park may dupe another employer increases. And when the misconduct and a lack of response are made public, public confidence in science takes another small knock. Park's plagiarism will not rock the physics community in the way that Schön's fraud did, but that is no excuse for acting as if it didn't happen at all.

\section{Nature's twentieth-century highs}

\section{Celebrating a book about discoveries that changed science.}

E very scientist, like Newton, stands on the shoulders of giants, but few stop to look directly at what those giants accomplished. The history and the documentation of all but the most recent of past discoveries is of concern only to historians, sociologists and scientists who are no longer actively engaged at the front line.

That, at least, is a view held by most young researchers. But a new book warrants their attention and that of anyone else interested in science: A Century of Nature: Twenty-one Discoveries that Changed Science and the World (University of Chicago Press).

Here we must declare an interest: the book is wholly devoted to this journal's content, and the editors of the book are, or were, colleagues. Laura Garwin was our North American editor and Tim Lincoln is our News and Views editor. But according to Freeman Dyson, "this book provides a much more solid basis for scientific literacy than the many popular books that are devoted to the latest scientific fad", and Jared Diamond and Steven Weinberg have celebrated its coverage across the disciplines. So the book's editors can be proud of it and we can be grateful to them and promote it with a clear conscience.

Some of the original papers almost leap off the page. The report in 1925 by Raymond Dart of his discovery of Australopithecus africanus, the first fossil link between apes and man, unabashedly presents a personal narrative. James Chadwick's report in 1932 of the discovery of the neutron has an almost casual brevity and informality about it that today's authors can only envy. In other cases it is the accompanying essays, many written by those working close to the original research, that bring the papers to life.

But whatever the topic — plate tectonics, extrasolar planets, T-cell immunology, the ozone hole, the generation of animal body plans, cloning - the essays also entice the reader into a far greater appreciation of the work than can be obtained when it is transmitted through textbooks. This collection of seminal papers shows that, like much-reproduced great paintings, however one may have been impressed at secondhand, there is something uniquely inspiring about the originals. 